\title{
Effect of Supercritical Ethanol Drying on the Properties of Zinc Oxide Nanoparticles
}

\author{
Theresa Egbuchunam ${ }^{1}$ and Devrim Balkose ${ }^{2}$ \\ ${ }^{1}$ Department of Chemistry, Federal University of Petroleum Resources, Effurun, Delta State, Nigeria \\ ${ }^{2}$ Chemical Engineering Department, Izmir Institute of Technology, Gulbahcekoyu, \\ Urla, Izmir, Turkey
}

\begin{abstract}
The synthesis, characterization, and application as polymers and anti-wear additives of nanosized zinc oxide particles obtained by conventional and supercritical ethanol drying are reported in this study. The nanaoparticles of $\mathrm{ZnO}$ produced by the two different drying techniques were characterized using Fourier Transform Infrared (FT-IR) spectrophotometry, Scanning Electron Microscopy (SEM), X-ray Diffraction (XRD) and Thermogravimetric analysis (TGA) to elucidate the shape, size, composition, and stability of the nanoparticles. $\mathrm{ZnO}$ nanoparticles were then applied to poly (vinyl chloride) (PVC) powder and light mineral oil to assess their effectiveness and suitability as additives in diverse areas. $\mathrm{XRD}$ analysis revealed $\mathrm{ZnO}$ crystalline structure with average particle size of $24.7 \mathrm{~nm}$ for zinc oxide nanoparticles prepared by supercritical ethanol drying while SEM showed well-isolated and monodisperse particles with average size of $61.08 \mathrm{~nm}$.
\end{abstract}

Keywords Mineral oil; Poly (vinyl chloride); Supercritical ethanol drying; Zinc oxide nanoparticles

\section{INTRODUCTION}

Nanoparticles are of considerable importance in numerous technological applications. The development of advanced functional nanomaterials for various applications, including catalysis, pigments, cosmetic sunscreens, textile materials, etc., ${ }^{[1-4]}$ have received considerable interest in the last few years. Nanomaterials possess useful properties ranging from novel optical, electronic, and chemical properties ${ }^{[5,6]}$ to sunscreens, paints, varnishes, plastics, cosmetics, ${ }^{[7]}$ and lubricants. ${ }^{[8]}$

Zinc oxide $(\mathrm{ZnO})$ is an important material used for a variety of applications such as chemical sensors, varistors, thin-film luminescent devices, catalysts, and cosmetic materials. ${ }^{[9]}$ Due to the diverse applications of $\mathrm{ZnO}$, the generation of highly dispersible materials homogeneously distributed in applied systems is of great importance as materials having a structure with a grain size in the nanometer range exhibit properties significantly different from

Correspondence: Theresa Egbuchunam, Department of Chemistry, Federal University of Petroleum Resources, Effurun, Delta State, Nigeria; E-mail: tessychunam@gmail.com those for the same material with larger grain size. Ultrafine zinc oxide particles show a high degree of transparency, making them useful, especially for broad UV-A and UV-B blocking. ${ }^{[7]}$

During production, nanoparticles agglomerate owing to the influence of interfacial tension during conventional drying. ${ }^{[9,10]}$ In order to prevent particle agglomeration during production, a number of new synthetic strategies have been developed to generate well-defined nanoparticles having structures and properties suitable for applications in aqueous and non-aqueous systems. Various methods for the preparation of metal oxide nanoparticles have been developed with the ultimate goal to produce particles of controllable properties including size distribution, morphology, and crystal structure. Amongst these methods is supercritical fluid drying, where the solvent is removed above its critical temperature $\left(T_{c}\right)$ and critical pressure $\left(P_{c}\right)$. High temperatures have been shown to be necessary in obtaining very fine particles as the liquid-vapor interface and capillary pressure are eliminated and the resulting particles do not tend to stick to each other. ${ }^{[7,11-13]}$

The unique properties of supercritical fluids, mainly water, carbon dioxide, organic solvents, usually alcohols, have been demonstrated as a route for the production of metal oxide particles as they allow controlled particle properties, such as morphology, structure, and particle size distribution. ${ }^{[14]}$ Ethanol is a green fuel of the future, which can be regenerated from biomass through photosynthesis; therefore, ethanol can be used as a renewable bio-fuel. Ethanol has been used as an effective polar modifier for water and carbon dioxide in the supercritical fluid extraction and in supercritical chromatography. ${ }^{[15]}$

The synthesis of zinc oxide $(\mathrm{ZnO})$ nanoparticles using various methods has been reported in the literature. ${ }^{[16-21]}$ The use of supercritical fluid drying of $\mathrm{ZnO}$ has been investigated previously. Han et al. ${ }^{[22]}$ prepared $\mathrm{ZnO}$ nanoparticles in supercritical methanol and supercritical water and obtained particles down to $10 \mathrm{~nm}$ size. Gao et al. ${ }^{[23]}$ dried alcoholic $\mathrm{ZnO}$ gels by supercritical carbon dioxide drying. Monolithic zinc oxide aerogels were prepared 
using supercritical carbon dioxide by Krumm et al. ${ }^{[24]}$ Optical absorption and emission profiles and photocatalytic properties of $\mathrm{ZnO}$ nanoparticles were enhanced by supercritical fluid drying.

The introduction of nanoparticles into various systems has been shown to improve the properties of the system. For example, the dispersion stability of nano-sized particles in base oil provides the system to be used as a lubricant. ${ }^{[25]}$ When $0.5-3 \%$ nano $\mathrm{ZnO}$ was added to polyalphaolefin and surfactant solutions, the wear scar diameters were not lowered compared to the control mixtures without $\mathrm{ZnO} .^{[26]}$ This was attributed to insufficient dispersion of nano $\mathrm{ZnO}$ particles by the surface active agents added to polyalphaolefin. The introduction of nano- $\mathrm{ZnO}$ into polymer networks, e.g., PVC, has been reported ${ }^{[27]}$ to improve the structural, mechanical, and thermal properties of pure PVC. However, the effect of nano $\mathrm{ZnO}$ on the thermal stability of PVC was not reported previously.

There are many studies made with $\mathrm{CO}_{2},{ }^{[22]}$ water, ${ }^{[21]}$ and methanol ${ }^{[20]}$ in supercritical drying of $\mathrm{ZnO}$. However, ethanol, which is a cheap and abundant solvent with lower critical pressure than other solvents such as $\mathrm{CO}_{2}$, water, and methanol, has not been used for supercritical drying of $\mathrm{ZnO}$. Thus, the preparation of zinc oxide nanoparticles by precipitation method and drying of the ethanol washed precipitates by conventional and supercritical ethanol drying were targeted in the present study. Removal of water and ethanol under supercritical conditions were made in order to prevent agglomeration of particles due to surface tension of liquid ethanol. The prepared zinc oxide nanoparticles were compared in properties by characterizing with SEM, X-ray diffraction, FTIR, and TGA. Their effects on PVC dehydrochlorination were investigated. Their dispersions in base oil were also tested as lubricants.

\section{MATERIALS AND METHODS Materials}

Zinc chloride $\left(\mathrm{ZnCl}_{2}\right)$ from Fluka, sodium hydroxide $(\mathrm{NaOH})$ from Merck, and ethanol (99.9\% purity) from Merck were used as received in preparing zinc oxide $(\mathrm{ZnO})$. All materials were used without further purification.

\section{Preparation of $\mathrm{ZnO}$ Nanoparticles}

Zinc oxide nanoparticles were prepared by the method developed by Belcheri et al. ${ }^{[2]}$ In a typical procedure, $11.0 \mathrm{~g}$ of $\mathrm{ZnCl}_{2}$ was dissolved in $400 \mathrm{~cm}^{3}$ of ultrapurified water at $50^{\circ} \mathrm{C}$ in a water bath. $32 \mathrm{~cm}^{3}$ of $5 \mathrm{~mol} \mathrm{dm}^{-3} \mathrm{NaOH}$ aqueous solution was added "dropwise" to the zinc chloride solution with gentle stirring $(125 \mathrm{rpm})$ over a period of 10 minutes at $50^{\circ} \mathrm{C}$ in a water bath. The particles were then separated from the supernatant dispersion by sedimentation and the resulting suspension washed firstly with ultrapurified water, centrifuged at $6,000 \mathrm{rpm}$ for $15 \mathrm{~min}$ utes, and secondly with ethanol and centrifuged also at $6,000 \mathrm{rpm}$ for 15 minutes. The wet solid was divided into two portions The first portion was left to dry at room temperature overnight and then placed in an air-circulating oven at $110^{\circ} \mathrm{C}$ until a constant weight was obtained after 3 hours ( $\mathrm{ZnO}-\mathrm{A})$.

The second portion was dried at $250^{\circ} \mathrm{C}$ and $7.2 \mathrm{MPa}$ above the critical conditions of ethyl alcohol (EtOH). The experiment was carried out using the supercritical extractor system as shown schematically in Figure 1. The system has a temperature-controlled $300 \mathrm{~cm}^{3}$ PARR 4561(PARR Instrument Company, Illinois, USA) reactor (A) and a $300 \mathrm{~cm}^{3}$ PARR collector (B). Both reactors had $5.8 \mathrm{~cm}$ inner diameter and $10.1 \mathrm{~cm}$ height. Thus, the net volume is $272 \mathrm{~cm}^{3}$. The temperature controller had the following properties: "Model: PARR 4836, Input Thermocouple Type: J, Operating Range: $0-800^{\circ} \mathrm{C}$, Readout Resolution: $1{ }^{\circ} \mathrm{C}$, Set point Resolution: $1{ }^{\circ} \mathrm{C}$, System Accuracy: $\pm 2^{\circ} \mathrm{C}$, Control Type: PID controller." The pressure of the reactor (A) was monitored with a T316 stainless-steel Bourdon tube, with $7 \times 10^{-3}$ $20.9 \mathrm{MPa}$ range having $\pm 1 \%$ system accuracy. The reactor is equipped with a cooling coil to be used in cooling the contents further after the temperature dropped below the boiling point of the solvent in the reactor.

Before heating the system, nitrogen gas is passed through the system to remove oxygen in the reactor and pipelines. The critical temperature and pressure of ethanol are $239.8^{\circ} \mathrm{C}$ and $6.14 \mathrm{MPa}$. The supercritical drying was made under supercritical conditions of $7.2 \mathrm{MPa}$ and $250^{\circ} \mathrm{C}$. In a typical experiment, $5.05 \mathrm{~g}$ of wet solid and $100 \mathrm{~cm}^{3}$ ethanol were placed in the $300 \mathrm{~cm}^{3}$ reactor (A) (PARR 5500 Series Compact Reactor) and then the system was flushed with nitrogen gas. After all the valves are closed, the reactor A was heated up to $250^{\circ} \mathrm{C}$.

When the temperature was $250^{\circ} \mathrm{C}$ and the pressure 7.2 $\mathrm{MPa}$, the valve between the high pressure reactor and collector was opened to release ethanol into the $300 \mathrm{~cm}^{3}$

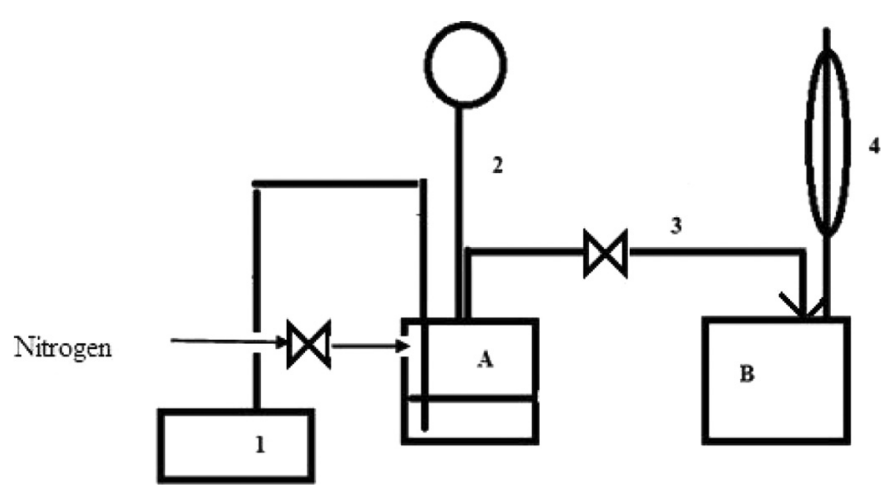

FIG. 1. Schematic representation of the supercritical drying system. 
collector (B) at room temperature. The valve was closed after the pressure decreased to nearly zero. The reactor system is allowed to cool to room temperaure. Ethanol mixed with water is condensed in reactor $\mathrm{B}$.

\section{Analysis of Ethanol Phase}

The volume $\%$ water present in the ethanol phase after supercritical drying was measured using a simple analytical method based on the conversion of the blue $\mathrm{CoCl}_{4}^{2-}$ to pink $\mathrm{Co}\left(\mathrm{H}_{2} \mathrm{O}\right)_{6}^{2+}$ by addition of water.

$$
\mathrm{CoCl}_{4}^{2-}+6 \mathrm{H}_{2} \mathrm{O} \rightarrow \mathrm{Co}\left(\mathrm{H}_{2} \mathrm{O}\right)_{6}^{2+}+4 \mathrm{Cl}^{-}
$$

The blue color of the ethanol solutions having $20 \mathrm{mg} \mathrm{CoCl} 2$. $6 \mathrm{H}_{2} \mathrm{O} / 100 \mathrm{~cm}^{3}$ ethanol and $0.5-2.0 \mathrm{~cm}^{3} \mathrm{H}_{2} \mathrm{O} / 100 \mathrm{~cm}^{3}$ ethanol was measured as the absorbance at $670 \mathrm{~nm}$ using a Perkin Elmer (Massachusetts, USA) Lambda 45 UV/VIS spetrophotometer. A calibration curve of absorbance versus water concentration was drawn.

The water present in ethanol after supercritical drying was determined by adding $20 \mathrm{mg} \mathrm{CoCl} 2 \cdot 6 \mathrm{H}_{2} \mathrm{O}$ to $100 \mathrm{~cm}^{3}$ sample and measuring the absorbance at $670 \mathrm{~nm}$. From the calibration curve, the water concentration was found.

\section{Characterization of ZnO Nanoparticles}

$\mathrm{ZnO}$ nanoparticles were prepared and dried by two methods: conventional (ZnO-A) and supercritical ethanol drying (ZnO-B) were characterized by various analytical methods. XRD was performed using an X-ray diffractometer (Philips Xpert-Pro from Panalytical, Almelo, Netherlands). The incident $\mathrm{CuK} \alpha$ radiation at $45 \mathrm{kV}$ and $40 \mathrm{~mA}$ with $1.54 \AA$ was used in the analysis. The scattering data were collected in the 5-70 $2 \theta$ range. The dried sample powders were prepared in a 0.5 -mm-thick holder. Fourier transform-infrared spectrophotometry (FT-IR) analysis was performed using a Shimadzu FTIR 8300S spectrophotometer from Shimadzu Kyoto, Japan. FT-IR was used to characterize the functional groups of the prepared nano$\mathrm{ZnO}$ particles. FT-IR spectra of the samples were obtained in the spectral range $4000-400 \mathrm{~cm}^{-1}$. Shimadzu TGA-51 was used for the thermogravimetric analysis of the samples. A small amount $(10-15 \mathrm{mg})$ of each sample was taken for the analysis and the samples were heated from room temperature up to $600^{\circ} \mathrm{C}$ at $10^{\circ} \mathrm{C} \mathrm{min}^{-1}$ under $\mathrm{N}_{2}$ flow of $40 \mathrm{~mL} \mathrm{~min}^{-1}$. SEM (Philips XL30 SFEG, FEI Company, Oregon, USA) images were used to observe the morphology of the samples. Conductive double-sided tape was used to fix the particles to the specimen holder before sputtering them with a thin layer of gold. The $\mathrm{Zn}, \mathrm{O}$, and $\mathrm{Cl}$ content of the $\mathrm{ZnO}$ nanoparticles were determined using elemental analyzer (Leco CHNS-932, Leco, Michigan, USA). Particle sizes of zinc oxide nanoparticles were determined using particle size analyzer Zetasizer 3000 HSA.
While using the zetasizer, the samples were dispersed in water by sonication.

\section{Properties of Zinc Oxide Nanoparticles \\ $\mathrm{ZnO}$ Nanoparticles as Polymer Additive}

The prepared samples were used as a polymer additive. PVC powder $(1 \mathrm{~g})$ and $0.1 \mathrm{~g}$ of the nano zinc oxide sample were blended thoroughly using an agate mortar and pestle. $0.5 \mathrm{~g}$ of this mixture was used to study the $\mathrm{HCl}$ evolution using conductivity measurements. Dehydrochlorination studies were carried out at 160 and $180^{\circ} \mathrm{C}$ using a Metrohm 763 PVC Thermomat (from Metrohm, Herisau, Switzerland) according to ISO 182-3. Metrohm 763 PVC Thermomat detects the evolution of $\mathrm{HCl}$ formed from the dehydrochlorination of PVC. The conductivity of the water solution to which the evolved $\mathrm{HCl}$ gas is transferred by carrier nitrogen gas versus time was measured and recorded. The measuring arrangement and experimental procedure of the Thermomat have been previously published. ${ }^{[28]}$

ZnO Nanoparticles as Anti-wear Additive in Oil Lubricants

The tribological property of $\mathrm{ZnO}$ nanoparticles in a mineral oil was studied. In a typical experiment, $50 \mathrm{~cm}^{3}$ of light mineral oil (TÜPRAŞ A.Ş.), $0.5 \mathrm{~g}$ of sorbitan monostearate (Span 60, Sigma-Aldrich) and $0.5 \mathrm{~g}$ of nanosized $\mathrm{ZnO}$ powder were mixed thoroughly at $160^{\circ} \mathrm{C}$ for one hour on a magnetic hot plate and left to cool at room temperature. Four ball tests were done to determine the friction coefficient and wear scar diameter using a Four Ball Tester from FALEX Corporation, Illinois, USA. The test was performed according to ASTM D 4172-94 at $392 \mathrm{~N}$ and the test duration was $1 \mathrm{~h}$.

\section{RESULTS AND DISCUSSION}

There are two opposing effects in supercritical drying of nanoparticles of $\mathrm{ZnO}$ : It may yield either nanoparticles of $\mathrm{ZnO}$, since there is no surface tension to agglomerate the particles during drying, or monolithic $\mathrm{ZnO}$ particles form due to the reinforcing effect of high pressure on the walls of macropores of $\mathrm{ZnO}$ hydrogels. ${ }^{[23]}$

\section{Supercritical Ethanol Extraction}

The amount of ethanol necessery to create the critical conditions in the reactor was calculated from the critical volume of ethanol $\left(0.2756 \mathrm{~g} \mathrm{~cm}^{3}\right)^{[27]}$ and the reactor volume. Since the cooling coil and thermocouple insert in the reactor also occupied nearly $10 \mathrm{~cm}^{3}$, the volume of the reactor was taken as $260 \mathrm{~cm}^{3}$ and $91 \mathrm{~cm}^{3}$ liquid ethanol was required to create the critical conditions. Thus, an excess of this volume, $100 \mathrm{~cm}^{3}$ ethanol, was added to the reactor to create supercritical conditions. 
The change of pressure and temperature during the heating process of the reactor is shown in Figure $2 \mathrm{a}$ and Figure $2 \mathrm{~b}$, respectively. The reactor contents reached supercritical conditions $\left(250^{\circ} \mathrm{C}\right.$ and $\left.7.2 \mathrm{MPa}\right)$ in $50 \mathrm{~min}-$ utes. The pressure-temperature diagram obtained during reaction is shown in Figure 2c. The measured change of pressure with temperature was very close to the predicted curve using the ancillary equation. ${ }^{[29]}$ In this ancillary equation, ethanol critical temperature $(513.9 \mathrm{~K})$ and pressure $(6.148 \mathrm{MPa})$ were used as given below.

$$
\begin{aligned}
\ln \frac{P}{P_{c}}= & \frac{T_{c}}{T}\left(-0.0514771 \theta^{1 / 2}-8.27075 \theta\right. \\
& \left.-5.49245 \theta^{3}+5.64829 \theta^{11 / 2}\right)
\end{aligned}
$$

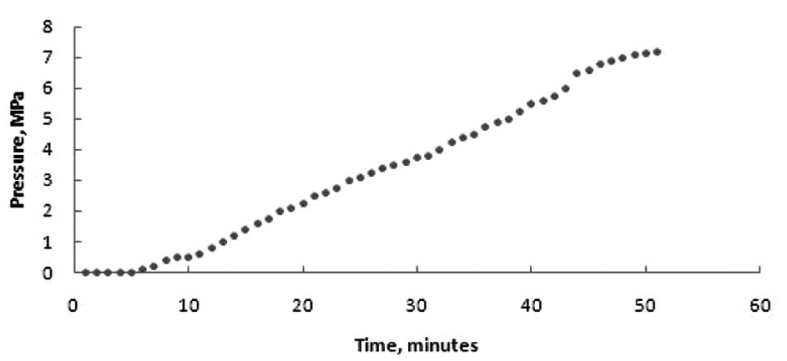

(a)

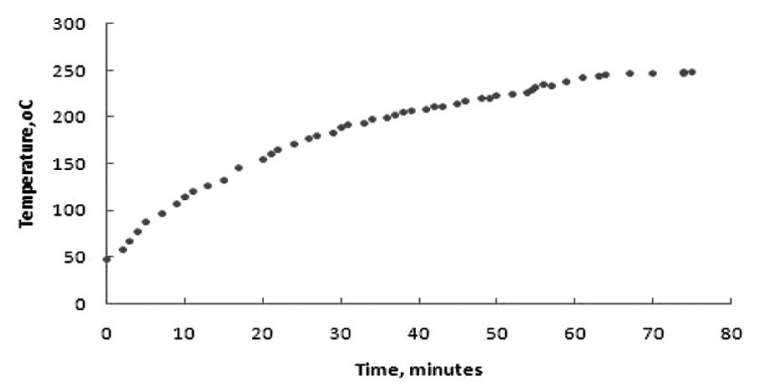

(b)

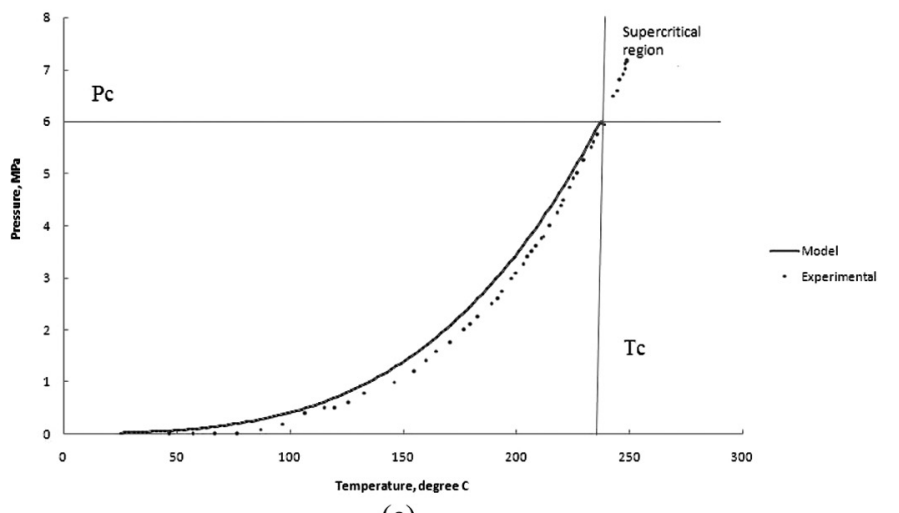

(c)

FIG. 2. (a) Pressure versus time; (b) Temperature versus time; (c) Pressure versus temperature during supercritical drying. where $\theta=1-(T / T c)$. It was noted that Equation (2) could be used to predict the vapor pressure of ethanol within $\pm 0.4 \%$. The critical pressure and temperature obtained in the experiments was very close to the theoretical values.

\section{The Material Balance}

Water was removed from the samples in several steps. The first step is separation of the precipitated wet powders from aqueous solution by centrifugation. The second step is washing the precipitate with ethanol and separation of the powders from ethanol phase by centrifugation. Water in the samples was replaced with ethanol during washing of the sample with ethanol and centrifuging. When the samples were dried either by conventional drying or supercritical ethanol drying, the water and ethanol were removed from the system. $100 \mathrm{~cm}^{3}$ liquid ethanol was recovered in reactor $\mathrm{B}$ after the supercritical ethanol drying process. Some amount of ethanol $\left(3-4 \mathrm{~cm}^{3}\right)$ remained in pipes and could not be recovered. The ethanol vapor present at $250^{\circ} \mathrm{C}$ and $0.1 \mathrm{MPa}$ in $300 \mathrm{~cm}^{3}$ reactor $\mathrm{A}$ was determined to be $0.31 \mathrm{~g}$ from an ideal gas equation. The ethanol remained in the reactor A after supercritical drying was not adsorbed by dried $\mathrm{ZnO}$, since the FTIR and TG analysis indicated that $\mathrm{ZnO}(\mathrm{ZnO}-\mathrm{B})$ collected in reactor A did not contain any ethanol. The water content of the recovered ethanol phase after supercritical drying process was determined as $0.32 \mathrm{~cm}^{3} / 100 \mathrm{~cm}^{3}$ ethanol $(0.38 \%$ in mass). Thus, from $5.05 \mathrm{~g}$ of sample placed in the reactor, $0.32 \mathrm{~g}$ water and $4.73 \mathrm{~g}$ ethanol were separated by supercritical ethanol drying. The FTIR spectrum of the dried sample showed that there was only a small amount of water in the sample. Table 1 shows the compositions of the inlet and outlet streams of the reactor A.

The water present in the samples before supercritical ethanol drying was calculated as $6.4 \%$ since all water was removed by supercritical drying. All water and ethanol should have been removed from the samples at the end of either conventional drying or supercritical ethanol drying since the temperatures of conventional and supercritical drying processes were well above the boiling points of ethanol and water.

\section{X-Ray Diffraction Measurements}

The XRD patterns of $\mathrm{ZnO}$ nanoparticles are shown in Figures $3 \mathrm{a}$ and $3 \mathrm{~b}$, respectively. The $\mathrm{X}$-ray diffraction exhibits the characteristic peaks for crystalline $\mathrm{ZnO}$ of hexagonal wurzite structure consistent with the standard values for $\mathrm{ZnO}{ }^{[30]}$ The sharp diffraction peaks indicate the good crystallinity of the prepared crystals. These peaks occurred at scattering angles $(2 \theta)$ of $31.588,34.228,36.097^{\circ}$ for $\mathrm{ZnO}-\mathrm{A}$, and $31.654,34.328,36.167^{\circ}$ for $\mathrm{ZnO}-\mathrm{B}$. The high intensity peaks for $\mathrm{ZnO}-\mathrm{A}$ and $\mathrm{ZnO}-\mathrm{B}$ belonged to diffractions from (100), (002), and (101) planes of $\mathrm{ZnO}$ with JCPDS card number 79-0206. ${ }^{[30]}$ Although the peaks 
TABLE 1

Composition of the streams in supercritical ethanol extraction assuming the solid phase is pure $\mathrm{ZnO}$

\begin{tabular}{lccc}
\hline Chemicals & $\begin{array}{c}\text { Initial composition of the } \\
\text { sample, mass } \%\end{array}$ & $\begin{array}{c}\text { Composition of the sample after } \\
\text { supercritical ethanol } \\
\text { drying, mass } \%\end{array}$ & $\begin{array}{c}\text { Composition of ethanol phase } \\
\text { after supercritical ethanol } \\
\text { extraction, mass } \%\end{array}$ \\
\hline ZnO & 57.7 & 90 & 0 \\
Ethanol & 36.9 & 10 & 99.62 \\
Water & 6.4 & 0 & 0.38 \\
\hline
\end{tabular}

occurring at $2 \theta$ values $11.1,16.6,22.0,22.4,24.7,28.18$ for both $\mathrm{ZnO}-\mathrm{A}$ and $\mathrm{ZnO}-\mathrm{B}$ samples is indicative of the presence of $\mathrm{Zn}_{5}(\mathrm{OH})_{8} \mathrm{Cl}_{2} \cdot \mathrm{H}_{2} \mathrm{O}$ with JCPDS card number $07-0155,{ }^{[31]}$ it is more pronounced in the former. The peak at $2 \theta 11.1^{\circ}$ belonged to $(003)$ planes of $\mathrm{Zn}_{5}(\mathrm{OH})_{8} \mathrm{Cl}_{2} \cdot \mathrm{H}_{2} \mathrm{O}$. The relative intensities of this to $2 \theta 36.1^{\circ}$ peak for $\mathrm{ZnO}-\mathrm{A}$ and $\mathrm{ZnO}-\mathrm{B}$ were 0.32 and 0.31 , respectively. This indicated that $\mathrm{ZnO}-\mathrm{B}$ had less $\mathrm{Zn}_{5}(\mathrm{OH})_{8} \mathrm{Cl}_{2} \cdot \mathrm{H}_{2} \mathrm{O}$ than $\mathrm{ZnO}$-A, possibly due to its removal or partial transformation of $\mathrm{Zn}_{5}(\mathrm{OH})_{8} \mathrm{Cl}_{2} \cdot \mathrm{H}_{2} \mathrm{O}$ to other products during heating up to $250^{\circ} \mathrm{C}$ in the supercritical ethanol drying process.

The relative intensities of the peak at $2 \theta 34.2^{\circ}$ of $(002)$ planes to $2 \theta 36.1^{\circ}$ peak of (101) planes for $\mathrm{ZnO}-\mathrm{A}$ and

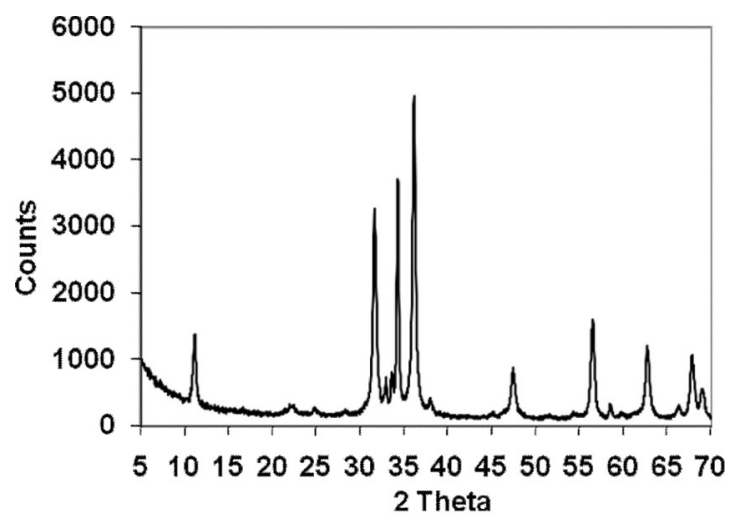

(a)

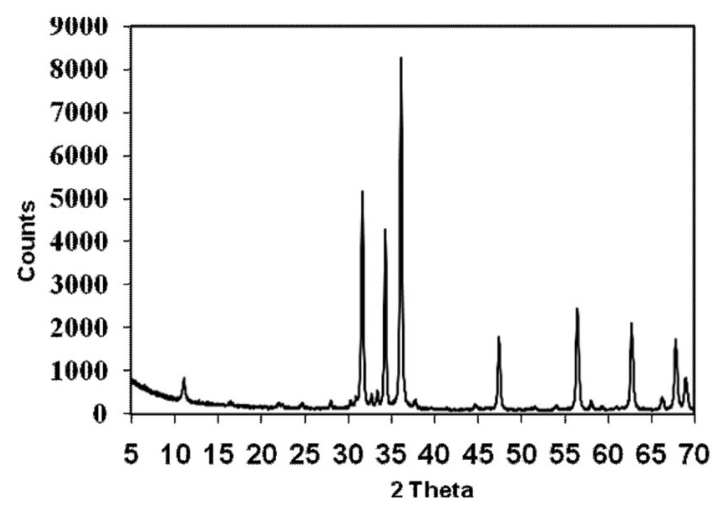

(b)

FIG. 3. XRD pattern for (a) nano $\mathrm{ZnO}-\mathrm{A}$; (b) nano $\mathrm{ZnO}-\mathrm{B}$.
$\mathrm{ZnO}-\mathrm{B}$ were 0.81 and 0.67 , respectively. İn bulk $\mathrm{ZnO}$, this ratio is reported as 0.42 in JCPDS card number 79-0206. Both $\mathrm{ZnO}-\mathrm{A}$ and $\mathrm{ZnO}-\mathrm{B}$ particles were oriented in c-directions since this ratio was greater than 0.42. Supercritical ethanol drying process decreased the orientation in c-direction but crystals were still oriented in c-direction compared to bulk $\mathrm{ZnO}$ crystals.

The average particle size of the $\mathrm{ZnO}$ nanoparticles was calculated for three prominent peaks, (100), (002), and (101), using the Scherrer equation

$$
L=\frac{K \lambda}{\beta \cos \theta}
$$

where $\beta$ is the measured full-width at half maximum (radians), $\theta$ is the Bragg peak angle of the peak, $\lambda$ is the $\mathrm{X}$-ray diffraction wavelength (in this case, it is $0.1546 \mathrm{~nm}$ ), $\mathrm{L}$ is the effective particle size, and $\mathrm{K}$ is a constant $=0.9$. The values are shown in Table 2.

The crystallite sizes $16.6,16.7$, and $16.8 \mathrm{~nm}$ estimated for (100), (002), and (101) diffraction lines were almost the same for $\mathrm{ZnO}-\mathrm{A}$. A higher crystallite, $27.7 \mathrm{~nm}$, was obtained from (100) planes compared to sizes of $25.5 \mathrm{~nm}$ and $21.0 \mathrm{~nm}$ obtained from (002) and (101) planes for $\mathrm{ZnO}-\mathrm{B}$. The average particle size calculated using the Scherrer formula was $16.7 \mathrm{~nm}$ for $\mathrm{ZnO}-\mathrm{A}$ and $24.7 \mathrm{~nm}$ for $\mathrm{ZnO}-\mathrm{B}$. The particles of $\mathrm{ZnO}$ increased in size by supercritical ethanol drying.

\section{FTIR Spectrophotometric Analysis}

Figure 4 shows the FTIR spectra of the synthesized $\mathrm{ZnO}$ nanoparticles.

The spectra clearly shows strong absorption bands at $407 \mathrm{~cm}^{-1}$ for $\mathrm{ZnO}-\mathrm{A}$ and $420 \mathrm{~cm}^{-1}$ for $\mathrm{ZnO}-\mathrm{B}$ associated

TABLE 2

Crystallite sizes of $\mathrm{ZnO}$ nanoparticles

\begin{tabular}{lcccc}
\hline $\begin{array}{l}\text { Sample } \\
\text { name }\end{array}$ & $\begin{array}{c}\text { Peak 1 } \\
\left(\mathrm{t}_{100}\right)\end{array}$ & $\begin{array}{c}\text { Peak 2 } \\
\left(\mathrm{t}_{002}\right)\end{array}$ & $\begin{array}{c}\text { Peak 3 } \\
\left(\mathrm{t}_{101}\right)\end{array}$ & $\begin{array}{c}\text { Average } \\
\text { size }\end{array}$ \\
\hline $\mathrm{ZnO}-\mathrm{A}$ & $16.6 \mathrm{~nm}$ & $16.7 \mathrm{~nm}$ & $16.8 \mathrm{~nm}$ & $16.7 \mathrm{~nm}$ \\
$\mathrm{ZnO}-\mathrm{B}$ & $27.7 \mathrm{~nm}$ & $25.5 \mathrm{~nm}$ & $21.0 \mathrm{~nm}$ & $24.7 \mathrm{~nm}$ \\
\hline
\end{tabular}




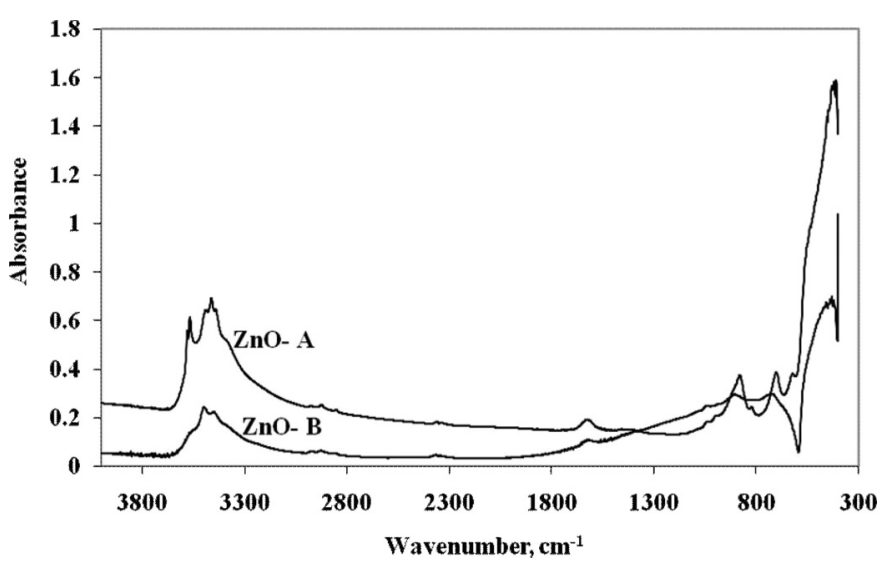

FIG. 4. FTIR spectra for synthesized $\mathrm{ZnO}$ nanoparticles.

with the characteristic vibrational mode of $\mathrm{Zn}-\mathrm{O}$ bonding. The broad absorption peaks between 3450 and $3560 \mathrm{~cm}^{-1}$ for $\mathrm{ZnO}-\mathrm{A}$ belonged $\mathrm{OH}$ stretching peaks of hydrogen bonded and isolated $\mathrm{O}-\mathrm{H}$ groups. $\mathrm{ZnO}-\mathrm{B}$ had only hydrogen bonded O-H groups vibrating at $3485 \mathrm{~cm}^{-1}$ for $\mathrm{ZnO}-\mathrm{B}$. There were no peaks in the region of $2900-2950 \mathrm{~cm}^{-1}$ related to symmetric and asymmetric streching vibrations of $\mathrm{CH}_{3}$ and $\mathrm{CH}_{2}$ groups of ethanol in the spectra of both samples. This indicated that $\mathrm{ZnO}-\mathrm{A}$ and $\mathrm{ZnO}-\mathrm{B}$ were free of ethanol. Both samples had a very small amount of adsorbed water having bending vibration at $1600 \mathrm{~cm}^{-1}$. The ratio of absorbance values at $3400 \mathrm{~cm}^{-1}$ for hydrogen bonded $\mathrm{OH}$ to $407 \mathrm{~cm}^{-1}$ for $\mathrm{Zn}-\mathrm{O}$ was around 4 for both samples, indicating that they had nearly the same concentration of hydrogen bonded $\mathrm{OH}$ groups. The peak of isolated $\mathrm{OH}$ groups at $3566 \mathrm{~cm}^{-1}$ disappeared by supercritical ethanol drying process. The peaks at 713 and $893 \mathrm{~cm}^{-1}$ attributed to $\mathrm{ZnO}$ stretching vibrations ${ }^{[32]}$ were broadened in supercritical ethanol drying process.

\section{Thermogravimetric Analysis}

The thermal behavior of $\mathrm{ZnO}$ nanoparticles was studied using TGA. The TG curves are shown in Figures $5 \mathrm{a}$ and $5 b$.

There is an instrument drift of the TG analyzer starting from $30^{\circ} \mathrm{C}$ up to $160^{\circ} \mathrm{C}$. The TG curves showed that there were no mass losses up to $160^{\circ} \mathrm{C}$. If ethanol was present in the samples, it would evaporate at its boiling point of $78^{\circ} \mathrm{C}$ and step mass loss would be observed at this temperature. Thus, TG analysis also indicated that there was no ethanol in both $\mathrm{ZnO}-\mathrm{A}$ and $\mathrm{ZnO}-\mathrm{B}$ samples. There were two steps in mass loss during haeting up to $600^{\circ} \mathrm{C}: 1.2 \%$ mass loss between $160-180^{\circ} \mathrm{C}$ and $2 \%$ between $375-400^{\circ} \mathrm{C}$. From XRD measurements, $\mathrm{Zn}_{5}(\mathrm{OH}) \mathrm{Cl}_{2} \cdot \mathrm{H}_{2} \mathrm{O}$ was present and with heat it decomposes finally, to form $\mathrm{ZnO}$ and $\mathrm{H}_{2} \mathrm{O}$ as shown in Equations (4)-(6). ${ }^{[32]}$ Reactions 4 and 6 should have occurred during the supercritical ethanol drying

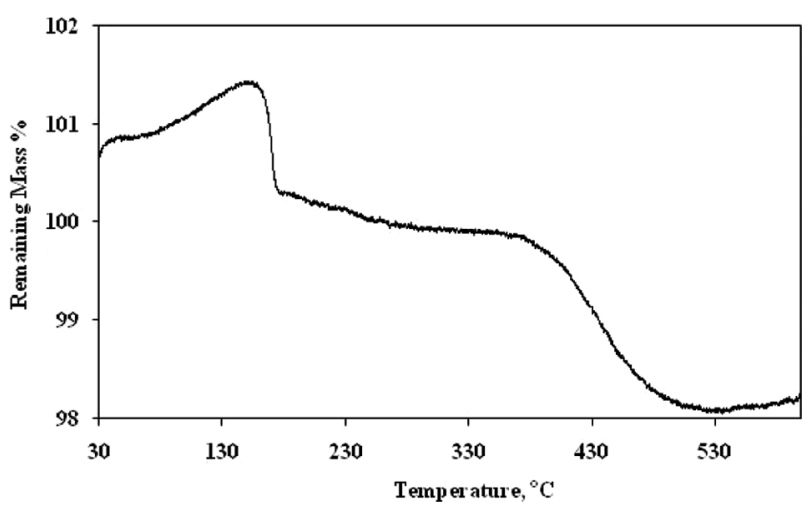

(a)

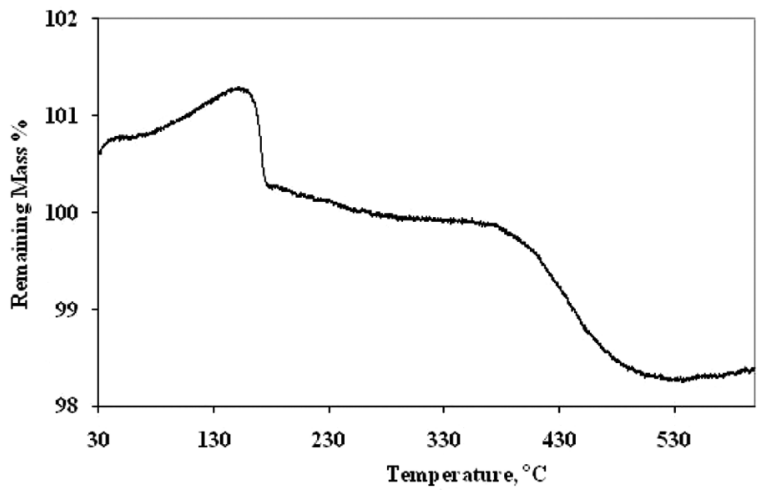

(b)

FIG. 5. TG curve for (a) nano $\mathrm{ZnO}-\mathrm{A}$; (b) nano $\mathrm{ZnO}-\mathrm{B}$.

process. However, both conventionally dried and supercritical ethanol dried samples had the same TG curves, indicating that the formed water was not separated from both samples during drying. Further heating in the TG analyzer allowed the evaporation of water in two steps starting at $160^{\circ} \mathrm{C}$ and $375^{\circ} \mathrm{C}$.

$$
\begin{aligned}
\mathrm{Zn}_{5}(\mathrm{OH})_{8} \mathrm{Cl}_{2} \cdot \mathrm{H}_{2} \mathrm{O}_{(\mathrm{s})} \rightarrow & \mathrm{Zn}_{5}(\mathrm{OH})_{8} \mathrm{Cl}_{2(\mathrm{~s})} \\
& +\mathrm{H}_{2} \mathrm{O}_{(\mathrm{g})} \text { at } 110-165^{\circ} \mathrm{C}
\end{aligned}
$$

$$
\begin{aligned}
\mathrm{Zn}_{5}(\mathrm{OH})_{8} \mathrm{Cl}_{2(\mathrm{~s})} \rightarrow & 2 \mathrm{Zn}(\mathrm{OH}) \mathrm{Cl}_{(\mathrm{s})} \\
+ & 3 \mathrm{ZnO}_{(\mathrm{s})}+3 \mathrm{H}_{2} \mathrm{O}_{(\mathrm{g})} \text { at } 165-210^{\circ} \mathrm{C} \\
2 \mathrm{Zn}(\mathrm{OH}) \mathrm{Cl}_{(\mathrm{s})} \rightarrow & \mathrm{ZnCl}_{2(\mathrm{~s})}+\mathrm{ZnO}_{(\mathrm{s})} \\
& +\mathrm{H}_{2} \mathrm{O}_{(\mathrm{g})} \text { at } 210-300^{\circ} \mathrm{C}
\end{aligned}
$$

\section{The Morphology of ZnO Nanoparticles}

Particle morphology and size were determined from scanning electron micrographs (SEM). Figures $6 \mathrm{a}$ and $6 \mathrm{~b}$ show the micrographs of $\mathrm{ZnO}-\mathrm{A}$ and $\mathrm{ZnO}-\mathrm{B}$ nanoparticles at 200 and $500 \mathrm{~nm}$ scales. 

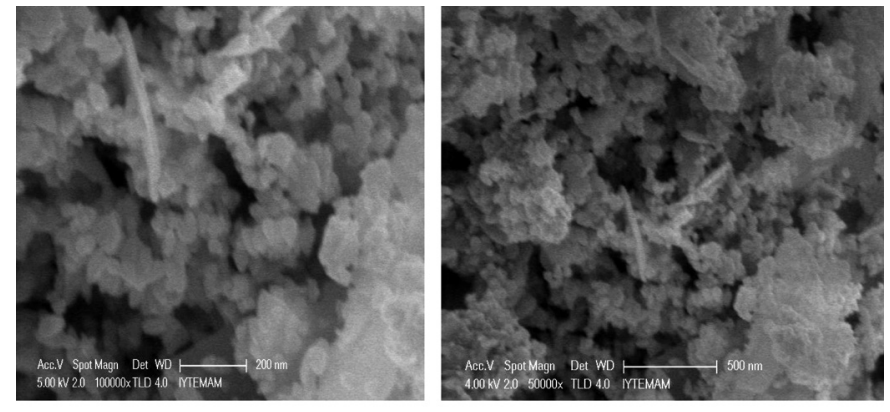

(a)
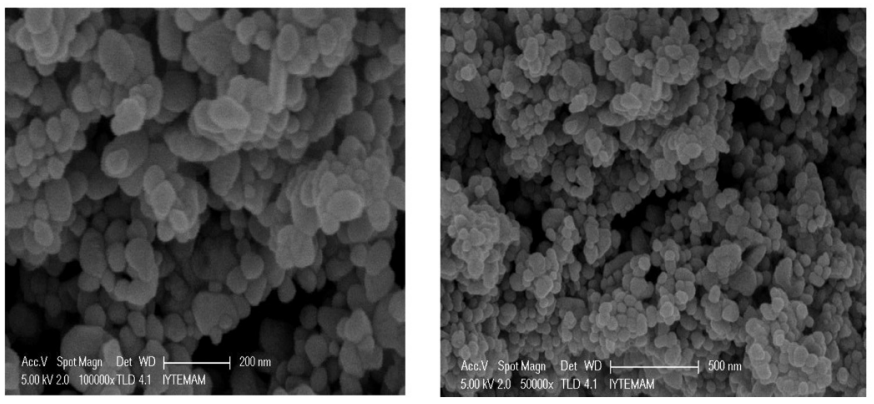

(b)

FIG. 6. SEM micrograph for (a) nano ZnO-A; (b) nano ZnO-B.

The SEM micrograph for $\mathrm{ZnO}-\mathrm{A}$ presents aggregates made of spherical particles that are in the range of 50 $100 \mathrm{~nm}$ with macropores between particles that have diameters larger than $50 \mathrm{~nm}$. Nanoparticles are nearly spherical and quite monodisperse. However, there are some larger aggregates in the sample obtained from conventional drying. ZnO-B nanoparticles obtained after supercritical ethanol drying are flat particles, more monodisperse and isolated. The average sizes for the particles using SEM measurements were 53.47 and $61.08 \mathrm{~nm}$ for $\mathrm{ZnO}-\mathrm{A}$ and $\mathrm{ZnO}-\mathrm{B}$, respectively. The crystal size of $\mathrm{ZnO}$ calculated from XRD data was smaller than that of the particles observed in SEM images. This indicates that the particles observed in SEM micrographs were agglomerated primary particles.

\section{EDX Analysis of the Samples and Reactions Occurring during the Precipitation Process}

The approximate composition of the samples determined by EDX analysis is shown in Table 3.

The values obtained are average values selected from three randomly chosen points. The results indicate that $\mathrm{ZnO}$ nanoparticles contained $>95 \% \mathrm{ZnO}$. However the $\mathrm{Zn}$ content was higher than expected for pure $\mathrm{ZnO}$. The chlorine content, $3.2 \%$ of the supercritical ethanol dried sample $\mathrm{ZnO}-\mathrm{B}$, was lower than that of the conventionally dried sample, 5.3\%. The lower chlorine content could be attributed to sublimation ${ }^{[33]}$ of $\mathrm{ZnCl}_{2}$ formed according
TABLE 3

EDX analysis of $\mathrm{ZnO}$ nanoparticles

\begin{tabular}{lccc}
\hline Sample & Zn (\%) & O (\%) & Cl (\%) \\
\hline ZnO-A & 81.1 & 13.6 & 5.3 \\
ZnO-B & 83.7 & 12.8 & 3.2 \\
Pure ZnO & 76.4 & 24.4 & 0.0 \\
\hline
\end{tabular}

to Equation (6). The EDX analysis of $\mathrm{ZnO}-\mathrm{A}$ and $\mathrm{ZnO}-\mathrm{B}$ samples indicated that during the precipitation reaction, pure $\mathrm{ZnO}$ was not formed, contrary to expectation. ${ }^{[2]} \mathrm{A}$ small amount of $\mathrm{Zn}_{5}(\mathrm{OH}) \mathrm{Cl}_{2} \cdot \mathrm{H}_{2} \mathrm{O}$ remained in $\mathrm{ZnO}$. The consecutive reactions shown by Equations (7)-(9) are thought to occur during precipitation.

$$
\begin{gathered}
\mathrm{ZnCl}_{2}+\mathrm{NaOH} \rightarrow \mathrm{Zn}_{5}(\mathrm{OH})_{8} \mathrm{Cl}_{2} \cdot \mathrm{H}_{2} \mathrm{O}+\mathrm{NaCl} \\
\mathrm{Zn}_{5}(\mathrm{OH})_{8} \mathrm{Cl}_{2} \cdot \mathrm{H}_{2} \mathrm{O}+2 \mathrm{NaOH} \rightarrow 5 \mathrm{Zn}(\mathrm{OH})_{2}+2 \mathrm{NaCl}+\mathrm{H}_{2} \mathrm{O}
\end{gathered}
$$

$$
\mathrm{Zn}(\mathrm{OH})_{2} \rightarrow \mathrm{ZnO}+\mathrm{H}_{2} \mathrm{O} \text { at } 50^{\circ} \mathrm{C}
$$

In the precipitation reaction, 1:2 molar ratio of $\mathrm{Zn}^{2+}$ and $\mathrm{OH}$ ions was used to ensure the formation of pure $\mathrm{ZnO}$. However, since $\mathrm{NaOH}$ was added dropwise to $\mathrm{ZnCl}_{2}$ solution initially, $\mathrm{Zn}_{5}(\mathrm{OH})_{8} \mathrm{Cl}_{2} \cdot \mathrm{H}_{2} \mathrm{O}$ was formed according to reaction 6 and some of it remained unchanged as $\mathrm{X}$-ray diffraction studies revealed.

\section{Particle Size Distribution}

The particle size was determined by means of dynamic light scattering on a Zetasizer 3000 HSA. Figures $7 \mathrm{a}$ and $7 \mathrm{~b}$ present size distributions (number average) of the $\mathrm{ZnO}$ nanoparticles.

The peak analyses obtained from the light scattering measurements are presented in Table 4.

Since $\mathrm{ZnO}$ particles were disc-shaped rather than spherical in shape, two consecutive runs of the particle size distribution in water were not identical but close to each other. The particles in water were more agglomerated in water than their dry state since higher average particle sizes were observed in Zetasizer than were observed in SEM pictures. $95 \%$ of the samples had $78.1 \mathrm{~nm}$ particle size in run 2 for $\mathrm{ZnO}-\mathrm{A}$ and $92 \%$ of the samples had $107.7 \mathrm{~nm}$ average particle size for $\mathrm{ZnO}-\mathrm{B}$. Since the particles were flat in shape and the Zetasizer assumes spherical particles, it was not possible to obtain identical size distributions for the same sample in consecutive runs.

However, supercritically dried $\mathrm{ZnO}$ had larger particles than conventionally dried samples, indicating $\mathrm{ZnO}$ particles were agglomerated in the supercritical drying process due to applied high pressure. The effect of pressure 


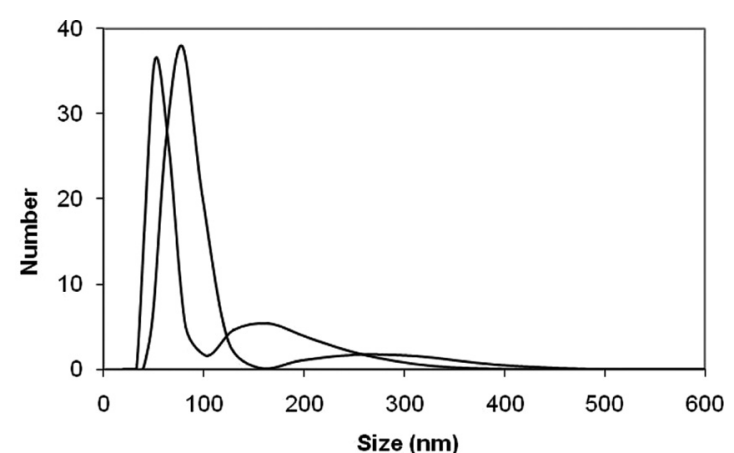

(a)

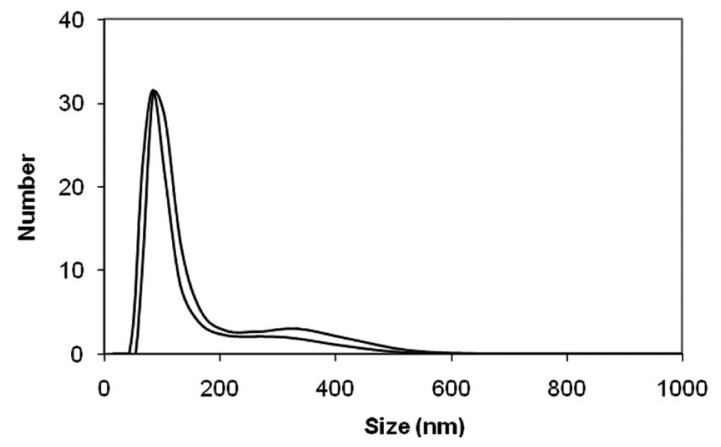

(b)

FIG. 7. Size distribution (number average) for (a) $\mathrm{ZnO}-\mathrm{A}$; (b) $\mathrm{ZnO}-\mathrm{B}$.

TABLE 4

Peak analysis for number average size distribution

\begin{tabular}{lcccc}
\hline & Peak & Area & Mean $(\mathrm{nm})$ & Width \\
\hline ZnO-A run 1 & 1 & 83.17 & 56.8 & 29 \\
ZnO-A run 2 & 1 & 95 & 78.1 & 43.9 \\
& 2 & 5 & 268.7 & 174.5 \\
ZnO-B run 1 & 1 & 100 & 104.4 & 55.2 \\
ZnO-B run 2 & 1 & 92.3 & 107.7 & 55.2 \\
& 2 & 7.7 & 340.3 & 113.4 \\
\hline
\end{tabular}

outweighs the absence of interfacial tension between the particles and the liquids that would keep the size of the initially formed nanoparticles constant without any agglomeration.

\section{APPLICATION POTENTIAL OF ZnO NANOPARTICLES IN DIVERSE AREAS \\ Zinc Oxide Nanoparticles as Polymer Additive}

Polymeric materials are of special interest because, in combination with suitable metal salts (lithium ions and/ or $\mathrm{ZnO}$ ), they give complexes that are useful for the development of advanced high-energy electrochemical devices, e.g., batteries, fuel cells, electrochemical display devices, and photoelectrochemical cells, with ease of fabrication into thin films of desirable sizes. ${ }^{[27]}$ Poly (vinyl chloride) (PVC) is one of the major thermoplastics used today, having large and broad uses in commerce. It has the unique ability to be compounded with a wide variety of additives, making it posible to produce materials in a range from flexible elastomers to rigid compounds. One of the problems associated with the processing and use of PVC is its low thermal stability. Metal soaps from zinc salts have been shown to be effective thermal stabilizers for PVC. ${ }^{[34-36]}$

The effect of the nanosized $\mathrm{ZnO}$ particles on the thermal stability of PVC powder was investigated using the 763 PVC Thermomat. The conductivity versus time curves obtained for the samples heated at 160 and $180^{\circ} \mathrm{C}$ are shown in Figures 8a and 8b, respectively.

Conductivity measurements provide an overall assessment of the relative effect of an additive on the process of dehydrochlorination of PVC. The induction time, stability time, and activation energies computed from values obtained from the induction times are presented in Table 5.

The induction time for pure PVC was $1.5 \mathrm{hr}$ and $0.76 \mathrm{hr}$ at $160^{\circ} \mathrm{C}$ and $180^{\circ} \mathrm{C}$, respectively. For $\mathrm{ZnO}-\mathrm{A}$ and $\mathrm{ZnO}-\mathrm{B}$ samples added to $\mathrm{PVC}$, the induction times at $160^{\circ} \mathrm{C}$ were

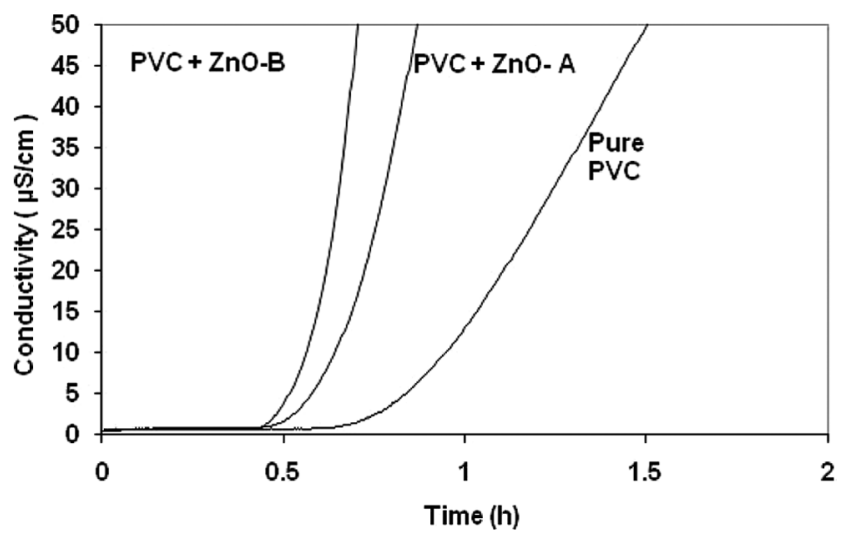

(a)

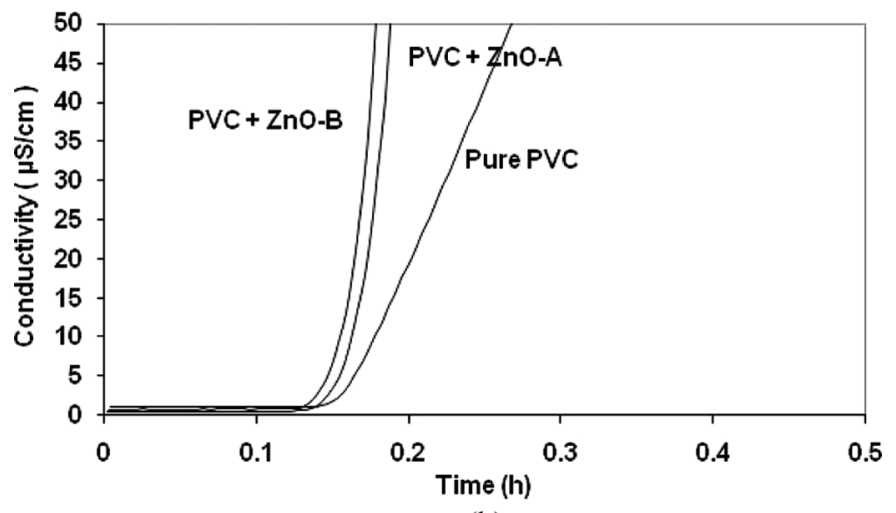

(b)

FIG. 8. Conductivity versus time curves for PVC and PVC having nanosized $\mathrm{ZnO}$ particles at (a) $160^{\circ} \mathrm{C}$; (b) $180^{\circ} \mathrm{C}$. 
TABLE 5

Onset time, stability time, and activation energy of the stability time from conductivity measurement from PVC thermomat

\begin{tabular}{|c|c|c|c|c|c|}
\hline \multirow[b]{2}{*}{ Sample } & \multicolumn{2}{|c|}{ Onset time, hr } & \multicolumn{2}{|c|}{ Stability time, $\mathrm{hr}$} & \multirow{2}{*}{$\begin{array}{l}\text { Activation energy of the } \\
\text { stability time, } \mathrm{kJ} / \mathrm{mol}\end{array}$} \\
\hline & $160^{\circ} \mathrm{C}$ & $180^{\circ} \mathrm{C}$ & $160^{\circ} \mathrm{C}$ & $160^{\circ} \mathrm{C}$ & \\
\hline PVC & 0.76 & 0.09 & 1.50 & 0.25 & 141.2 \\
\hline $\mathrm{PVC}+\mathrm{ZnO}-\mathrm{A}$ & 0.74 & 0.20 & 0.87 & 0.26 & 126.3 \\
\hline $\mathrm{PVC}+\mathrm{ZnO}-\mathrm{B}$ & 0.71 & 0.18 & 0.73 & 0.19 & 116.3 \\
\hline
\end{tabular}

not changed extensively compared to the control sample. The induction time increased from $0.09 \mathrm{hr}$ to 0.20 and $0.18 \mathrm{hr}$ by $\mathrm{ZnO}-\mathrm{A}$ and $\mathrm{ZnO}-\mathrm{B}$ addition, respectively, indicating the stabilizing action of both $\mathrm{ZnO}$ samples at this temperature. After onset of the dehydrochlorination, the added $\mathrm{ZnO}$ samples accelerated the dehydrochlorination reaction of PVC and the stability time at $160^{\circ} \mathrm{C}$ decreased from $1.5 \mathrm{hr}$ to 0.87 and $0.73 \mathrm{hr}$ for $\mathrm{ZnO}-\mathrm{A}$ and $\mathrm{ZnO}-\mathrm{B}$, respectively. A similar behavior was observed at $180^{\circ} \mathrm{C}$ and stability time decreased from $0.25 \mathrm{hr}$ to 0.19 and $0.18 \mathrm{hr}$ for $\mathrm{ZnO}-\mathrm{A}$ and $\mathrm{ZnO}-\mathrm{B}$ addition.

It is expected that the addition of an additive to PVC should result in higher values of activation energy for the dehydrochlorination if it acts as a heat stabilizer. However, the addition of $\mathrm{ZnO}$ nanoparticles lowered the energy of activation from $141.2 \mathrm{~kJ} / \mathrm{mol}$ to 126.3 and $116.3 \mathrm{~kJ} / \mathrm{mol}$ for $\mathrm{ZnO}-\mathrm{A}$ and $\mathrm{ZnO}-\mathrm{B}$, respectively. The activation energy of the control PVC sample was close to the values determined in previous studies. ${ }^{[36]}$ From the values, the addition of nanosized $\mathrm{ZnO}$ powder to PVC accelerated dehydrochlorination after onset of dehydrochlorination with more notable changes occurring in $\mathrm{ZnO}-\mathrm{B}$. The $\mathrm{ZnO}$ powders could be efficiently used in dehydrochlorination of waste $\mathrm{PVC}$ to obtain $\mathrm{HCl}$.

\section{$\mathrm{ZnO}$ Nanoparticles as Anti-wear Additive in Oil Lubricants}

Numerous nanoparticles used as oil additives have been investigated in recent years and results show that they deposit on the rubbing surface and improve the tribological properties of the base oil, displaying good friction and wear reduction characteristics even at concentrations below $2 \mathrm{wt} \% .{ }^{[8]}$ Commercially available lubricants contain base oil and functional additive packages to achieve a desired performance for a specific application. Antiwear additives are used to react with surfaces in contact to form a protective layer, which ensures that sporadic asperity contacts does not lead to severe wear. ${ }^{[37]}$ Nanoparticles of $\mathrm{ZnO}$ were used as a friction-reducing and antiwear additive for poly alpha olefin 6 in a previous study. ${ }^{[8,26]}$ In the present study, $\mathrm{ZnO}$ samples dried conventionally and by supercritical ethanol drying were used for the same purpose. The wear scar surfaces of lower balls of the four ball tester are seen in Figure 9 for $\mathrm{ZnO}-\mathrm{A}$ and $\mathrm{ZnO}-\mathrm{B}$ added lubricants.

The wear scar diameter and friction coefficients of $\mathrm{ZnO}-\mathrm{A}$ and $\mathrm{ZnO}-\mathrm{B}$ added lubricants (Table 6) were smaller than paraffin oil but higher than the paraffin oil with Span 60. While ZnO-A had a lower friction coefficient $(0.085)$ than $\mathrm{ZnO}-\mathrm{B}(0.96)$, the wear scar diameter $(0.079 \mathrm{~mm})$ was lower for $\mathrm{ZnO}-\mathrm{B}$ than for $\mathrm{ZnO}-\mathrm{A}(1.145 \mathrm{~mm})$. Thus, a compromise should be made to either lower friction coefficient or wear scar diameter by using two different $\mathrm{ZnO}$ samples. Battez et al. ${ }^{[26]}$ also observed an increase in wear scar diameter when nano $\mathrm{ZnO}$ was added to non-ionic surfactant added polyolefin oil. A similar behavior was observed in the present study for both $\mathrm{ZnO}-\mathrm{A}$ and $\mathrm{ZnO}-\mathrm{B}$ particles, indicating they were not dispersed in the oil. Even if they were softer than steel balls, when squeezed between

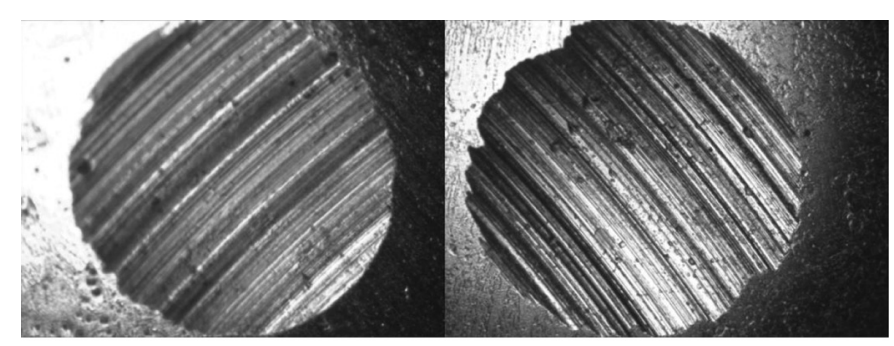

(a)

(b)

FIG. 9. Wear scar diameter of balls tested with using lubricant prepared from (a) $\mathrm{ZnO}-\mathrm{A}$; (b) $\mathrm{ZnO}-\mathrm{B}$.

TABLE 6

Friction coefficient and wear scar diameter of lubricants

\begin{tabular}{lcc}
\hline Sample & $\begin{array}{c}\text { Friction } \\
\text { coefficient }\end{array}$ & $\begin{array}{c}\text { Wear scar } \\
\text { diameter, mm }\end{array}$ \\
\hline Oil (Atakul et al., 2011) & 0.099 & 1.402 \\
Oil + Span 60 (Atakul & 0.064 & 0.639 \\
$\quad$ et al., 2011) & & \\
Oil + Span 60+ ZnO-A & 0.085 & 0.961 \\
Oil + Span 60+ZnO-B & 0.079 & 1.145 \\
\hline
\end{tabular}


the rotating upper ball and fixed lower balls they were hardened and eroded the steel surface.

\section{CONCLUSIONS}

$\mathrm{ZnO}$ nanoparticles were obtained by conventional and supercritical ethanol drying. The EDX analysis, X-ray diffraction, and TG analysis indicated that they contained small amounts of $\mathrm{Zn}_{5}(\mathrm{OH})_{8} \mathrm{Cl}_{2} \cdot \mathrm{H}_{2} \mathrm{O}$, which decomposed partially during the supercritical ethanol drying process. The nanoparticles having $16.7 \mathrm{~nm}$ size were transformed to larger particles with $24.7 \mathrm{~nm}$ size by supercritical ethanol drying. The average sizes for the particles using SEM measurements were 53.47 and $61.08 \mathrm{~nm}$ for $\mathrm{ZnO}-\mathrm{A}$ and $\mathrm{ZnO}-\mathrm{B}$, respectively. The particles were aggregated to larger particles, $78.1 \mathrm{~nm}$ and $107.7 \mathrm{~nm}$ sizes for $\mathrm{ZnO}-\mathrm{A}$ and $\mathrm{ZnO}-\mathrm{B}$, respectively, in water. The absence of surface tension of liquid ethanol during supercritical ethanol drying was not sufficient to prevent agglomeration of the particles. Due to very high pressure used in supercritical extraction, the particles obtained were more agglomerated compared to the particles obtained by conventional drying at atmospheric pressure. The supercritically dried $\mathrm{ZnO}$ dehydrochlorinated PVC faster than conventionally dried $\mathrm{ZnO}$. While a lubricant with $\mathrm{ZnO}-\mathrm{A}$ had a lower friction coefficient than the lubricant with $\mathrm{ZnO}-\mathrm{B}$, the wear scar diameter was lower for $\mathrm{ZnO}-\mathrm{B}$ than for $\mathrm{ZnO}-\mathrm{A}$. The supercritical ethanol drying of zinc oxide could be used for the purpose of obtaining more active PVC dehydrochlorination catalyst.

\section{ACKNOWLEDGMENT}

The authors acknowledge Senem Yetgin from the Chemical Engineering Department of Izmir Institute of Technology for her contributions in data analysis.

\section{REFERENCES}

1. Mo, L.; Zheng, C.; Yeh, T. A novel $\mathrm{CeO}_{2} / \mathrm{ZnO}$ catalyst for hydrogen production from the partial oxidation of methanol. Chem. Phys. Chem. 2005, 6, 1470-1472.

2. Becheri, A.; Dürr, M.; Lo Nostro, P.; Baglioni, P. Synthesis and characterization of zinc oxide nanoparticles: Application to textiles as UV-absorbers. Journal of Nanoparticle Research 2008, 10, 679-689.

3. Mishra, B.G.; Rao, G.R. Promoting effect of ceria on the physicochemical and catalytic properties of $\mathrm{CeO}_{2}-\mathrm{ZnO}$ composite oxide catalysts. Journal of Molecular Catalysis A 2006, 243, 204-213.

4. Guo, L.; Yang, S. Synthesis and characterization of poly(vinyl pyrrolodone)-modified zinc oxide nanoparticles. Chemistry of Materials 2000, 12, 2268-2274.

5. Oliveira, A.A.; Hochepied, J.F.; Grillon, F.; Berger, M.H. Controlled precipitation of zinc oxide particles at room temperature. Chemistry of Materials 2003, 15, 3202-3207.

6. Tang, E.; Cheng, G.; Ma, X.; Pang, X.; Zhao, Q. Surface modification of zinc oxide nanoparticle by PMAA and its dispersion in aqueous system. Applied Surface Science 2006, 252, 5227-5232.

7. Viswanathan, R.; Daniel Lilly, G.; Gale, W.F.; Gupta, R.B. Formation of zinc oxide-titanium dioxide composite nanoparticles in supercritical water. Industrial \& Engineering Chemistry Research 2003, 42, 5535-5540.

8. Hernández, B.A.; González, R.; Viesca, J.L.; Fernández, J.E.; Díaz Fernández, J.M.; Machado, A.; Chou, R.; Riba, J. CuO, $\mathrm{ZrO}_{2}$ and $\mathrm{ZnO}$ nanoparticles as antiwear additive in oil lubricants. Wear 2008, $265,422-428$.

9. Gönen, M.; Balköse, D.; Gupta, R.B.; Ülkü, S. Supercritical carbon dioxide drying of methanol-zinc borate mixtures. Industrial \& Engineering Chemistry Research 2009, 48, 6869-6876.

10. Wang, B.; Zhang, W.; Zhang, W.; Yu, C.; Wang, G.; Huang, L.; Mujumdar, A.S. Influence of drying processes on agglomeration and grain diameters of magnesium oxide nanoparticles. Drying Technology 2007, 25, 715-721.

11. Mujumdar, A.S.; Huang, L.X. Global R\&D needs in drying. Drying Technology 2007, 25, 647-658.

12. Masmoudi, Y.; Rigacci, A.; Ilbizian, P.; Cauneau, F.; Achard, P. Diffusion during the supercritical drying of silica gels. Drying Technology 2006, 24, 1121-1125.

13. Tachiwaki, T. Supercritical fluid drying of aqueous 2-propanol suspension. Drying Technology 2004, 22(1-2), 324-334.

14. Ma, C.; Chang, T.; Ye, W.; Duan, L.; Wang, C. Hexagon $\gamma$-alumina nanosheets produced with the assistance of supercritical ethanol drying. Journal of Supercritical Fluids 2008, 45, 112-120.

15. Polikhronidi, N.G.; Abdulagatov, I.M.; Stepanov, G.V.; Batyrova, R.G. Isochoric heat capacity measurements for pure ethanol in the near-critical and supercritical regions. Journal of Supercritical Fluids 2007, 43, 1-24.

16. Tsuzuki, T.; McCormick, P.G. ZnO nanoparticles synthesised by mechanochemical processing. Scripta Materialia 2001, 44, 17311734.

17. Wang, J.; Gao, L. Synthesis and characterization of $\mathrm{ZnO}$ nanoparticles assembled in one-dimensional order. Inorganic Chemistry Communications 2003, 6, 877-881.

18. Merchant, J.; Cocivera, M. Preparation and doping of zinc oxide using spray pyrolysis. Chemistry of Materials 1995, 7, 1742-1749.

19. Tsvigunov, A.N. A new modification of zinc oxide synthesized by the hydrothermal method. Glass and Ceramics 2001, 58(7-8), 280-282.

20. Veriansyah, B.; Kim, J.D.; Koun, B.; Ho, M.Y.; Youn-Woo, S.; Kim, L.K. Continuous synthesis of surface-modified zinc oxide nanoparticles in supercritical methanol. Journal of Supercritical Fluids 2010, $52,76-83$.

21. Viswanathan, R.; Gupta, R.B. Formation of zinc oxide nanoparticles in supercritical water. Journal of Supercritical Fluids 2003, 27, 187-193.

22. Han, N.S.; Shim, H.S.; Seo, J.H.; Park, S.M.; Min, B.K. Optical properties and lasing of $\mathrm{ZnO}$ nanoparticles continuously in supercritical fluids. Chemical Physics Letters 2011, 505, 51-56.

23. Gao, P.; Sisk, C.N.; Hope-Weeeks, L.J. A sol-gel route to synthesize monolithic zinc oxide aerogels. Chemistry of Materials 2007, 19, 60076011.

24. Krumm, M.; Pueyo, C.L.; Polarz, S. Monolithic zinc oxide aerogels from organometallic sol-gel precursors. Chemistry of Materials 2010, 22(18), 5129-5136.

25. Atakul Savrik, S.; Balköse, D.; Ülkü, S. Synthesis of zinc borate by inverse emulsion technique for lubrication. Journal of Thermal Analysis \& Calorimetry 2011, 104(2), 605-612.

26. Battez, A.H.; Rico, J.E.F.; Arias, A.N.; Rodriguez, J.L.V.; Rodriguez, R.C.; Fernandez, J.M.D. The tribological behaviour of $\mathrm{ZnO}$ nanoparticles as an additive to PAO6. Wear. 2006, 261(3-4), 256-263.

27. Elashmawi, I.S.; Hakeem, N.A.; Marei, L.K.; Hanna, F.F. Structure and performance of $\mathrm{ZnO} / \mathrm{PVC}$ nanocomposites. Physica B 2010, 405, $4163-4169$. 
28. Atakul, S.; Balköse, D.; Ülkü, S. Synergistic effect of metal soaps and natural zeolite on poly (vinyl chloride) thermal stability. Journal of Vinyl \& Additive Technology 2005, 11, 47-56.

29. Dillon, H.E.; Penoncello, S.G. A fundamental equation for calculation of the thermodynamic properties of ethanol. International Journal of Thermophysics, 2004, 25, 321-335.

30. Albertsson, J.; Abrahams, S.C.; Kvick, Å. Atomic displacement, anharmonic thermal vibration, expansivity and pyroelectric coefficient thermal dependencies in ZnO. Acta Crystallographica B, 1989, 45, 34- 40.

31. Tanaka, H.; Futoyu, A.; Fujioka, A.; Kandori, K.; Ishikawa, T. Influence of $\mathrm{Ti}(\mathrm{IV})$ on the structure and properties of zinc hydroxychloride. Corrosion Science 2008, 50, 3154-3159.

32. http://en.wikipedia.org/wiki/Zinc chloride (accessed October 10, 2011).

33. Rice, D.W.; Gregory, N.W. Vaporization characteristics of zinc chloride, bromide and iodide. Journal of Physical Sciences 1968, 72, 3361-3366.
34. Baltacioğlu, H.; Balköse, D. Effect of zinc stearate and/or epoxidized soybean oil on gelation and thermal stability of PVC-DOP plastigels. Journal of Applied Polymer Science 1999, 74, 2488-2498.

35. Benaniba, M.T.; Belhareche-Bensemra, N.; Gelbard, G. Stabilization of PVC by epoxidized sunflower oil in the presence of zinc and calcium stearates. Polymer Degradation \& Stability 2003, 82, 245-249.

36. Egbuchunam, T.O.; Balköse, D.; Okieimen, F.E. Effect of zinc soaps of rubber seed oil (RSO) and/or epoxidised rubber seed oil (ERSO) on the thermal stability of PVC plastigels. Polymer Degradation \& Stability 2007, 92, 1572-1582.

37. Naveira, S.A.; Grahn, M.; Pasaribu, R.; Larsson, R. The influence of base oil polarity on the tribological performance of zinc dialkyl dithiophospate additives. Tribology International 2010, 43, 22682278 . 